\title{
THE IMPORTANCE OF MICRO- AND MACROFLORA FROM BATOȚI (MEHEDINȚI DISTRICT) IN THE FRAME OF THE PALEOFLORISTIC HERITAGE OF ROMANIA
}

\author{
FLORINA DIACONU ${ }^{1}$, NICOLAE ȚICLEANU ${ }^{2}$, IUSTINIAN PETRESCU ${ }^{3}$, \\ VICTOR BARBU ${ }^{2} \&$ CORNEL MEILESCU ${ }^{4}$
}

\begin{abstract}
A rich microfloral assemblage consisting of over 125 taxa, and, up-to-date a macrofloral assemblage consisting of 25 taxa, has been described from Lower Pontian deposits from Batoți (Mehedinți district). The macroflora - the single one of this age in Romania - is allochthonous, partly hypautochthonous, and it has a special significance in understanding the evolution of the vegetation and climate of the Late Miocene.
\end{abstract}

Keywords: Early Pontian, microflora, macroflora, Batoți, SW Romania

\section{INTRODUCTION}

The presence of fossil plants in the Lower Pontian deposits cropping out north from Batoți was first mentioned by one of the authors (Meilescu). The fossiliferous site from Batoți is located at $12 \mathrm{~km}$ south from Turnu Severin municipality, on the left side of the Danube at the extremity of the low terrace $(7 \mathrm{~m}$ high) of the river.The succession dominated by clayey deposits includes a rich fossil vegetal association.

Petrescu et al. (2002) were the first to study this site, focusing on the exceptional palinologic content of the Lower Pontian deposits. Five species of microflora were identified by the authors: Glyptostrobus europaeus, Alnus kefersteini, Salix varians, Quercus pseudocastanea şi Fagus pliocaenica.

The first macrofloral study (Ticleanu et al., 2002) evidenced and illustrated the following taxa: Taxodium dubium, Glyptostrobus europaeus, Platanus platanifolia, Alnus ducalis, Alnus cecropiaefolia, Betula insignis, Fagus silesiaca, F. pliocaenica, Quercus kovatsi, Q. pontica miocaenica, Quercus cf. macrantheroides, Ulmus pyramidalis, Pterocarya paradissiaca, Populus populina and Byttneriophyllum tiliaefolium.

Diaconu (in press) added 7 new taxa to the floral list of this site: ? Sequoia gigantea, Liquidambar europaea, Castanea cf. crenata, Carya serraefolia, Acer integerrimum, Vitis teutonica, Cornus $s p$. and reconfirmed the presence of Alnus cecropiaefolia; to summarize, the Pontian floral association from Batoti reached a number of 24 taxa. It can be added that at least other 15 taxa contained in samples collected up-to-date are under study and will be presented elsewhere.

\footnotetext{
${ }^{1}$ Portile de Fier Museum, Drobeta Turnu Sverin

2 University of Bucharest, Faculty of Geology and Geophysics

3 Babeş- Bolyai University, Cluj Napoca

${ }^{4}$ 64/9 Alion str., 1500 Drobeta Turnu Severin
} 


\section{GEOLOGY}

Structurally, the Pontian deposits from Batoți are included in the Neogene cover of the external sector of the Carpathian Foredeep, in deposits accumulated on the western border of the Dacic Basin.

Ghenea \& Ghenea (1962) mentioned the presence of Pontian deposits in the region between $\mathrm{Tr}$. Severin and Batoți. These formations have significant extensions along the Danube side, starting from Turnu Severin and continuing south- and southeastwards. Based on outcrops and boreholes samples, it can be stated that the Early Pontian consists of interlayers of clays and marls, while sands dominate the Late Pannonian.

From Early Pontian clays, marly clays and sandy clays outcropping on the Danube side between Turnu Severin and Batoti, a fossil macrofauna with Congeria rhomboidea rumana Ştefănescu, C. rhomboidea rhomboidea Hoernes, Paradacna abichi Hoernes, Dreissenomya aperta Deshayes, Valenciennsia sp., etc. was described.

The deposits rich in fossil flora from Batoți (fig. 1) are mainly represented by stratified clays with fossil plant remains, besides which siltic clays and sandy silts, including carbonate sandstone concretions - also containing plant impressions, occur.

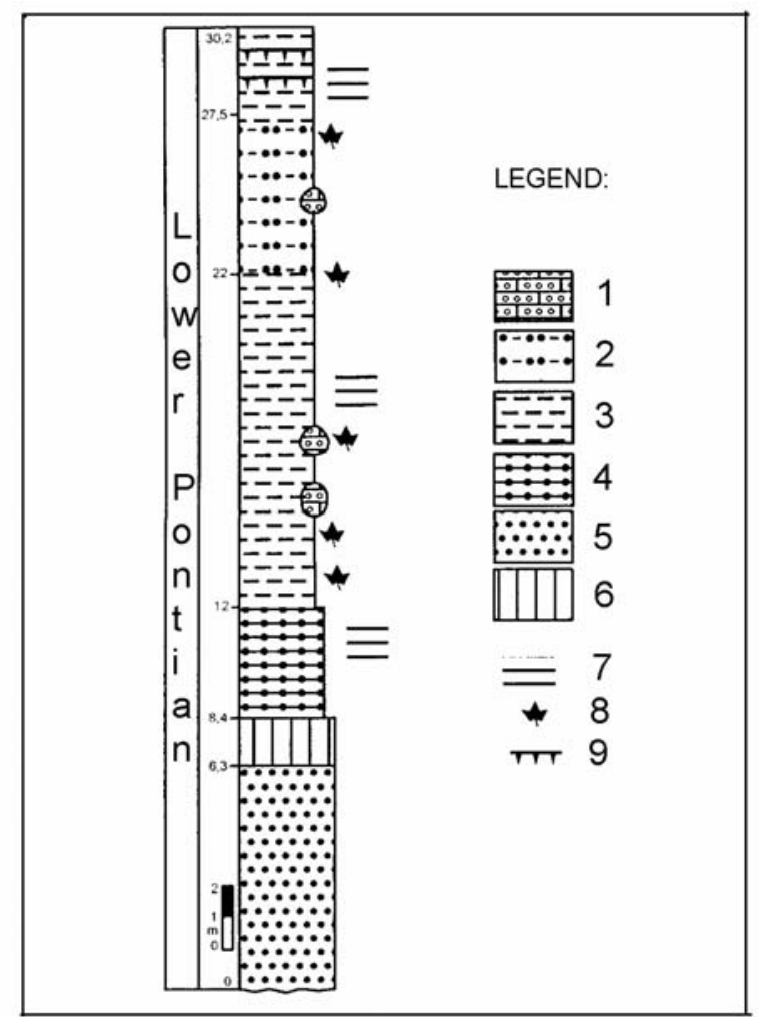

Fig. 1 - Lithological column (fossiliferous site Batoți). 1 - carbonate sandstone, 2 - clay with sandy films, 3 - clay, 4 - siltic clay, 5 - siltic sand, 6 - missing information, 7 - parallel stratification, 8 - foliar impressions, 9 - limonite laminae. 
On the top of the Lower Pontian deposits, a succession of sandy clays interlayered with clays and clay sands are cropping out along the Danube side, southwest from Drobeta Turnu Severin (Starmina Hill). The fossil macrofauna is represented, among others, by: Phyllocardium planum planum Deshayes, Arpacardium peregrinum Eberzin, Arpacardium mayeri Hoernes, Limnocardium apertum Münster, Pterodacna edentula Deshayes, Caladacna steindachneri Brusina, Dreissenomya aperta Deshayes, Valenciennsia annulata Rousseau, indicating the Late Pontian.

\section{TAPHONOMIC CONSIDERATIONS}

The Lower Pontian succession cropping out in the fossiliferous site is about $30 \mathrm{~m}$ thick; only the stratified clays with local variegated features, a few meters thick, contain fossil plant remains. Most of these rests occur as course vegetal detritus, frequently preserving more or less entire plant impressions, and rarely complete ones.

The high frequency of vegetal detritus and its location along a few millimeters in the lower part of very thin $(2-3 \mathrm{~cm})$ clay layers plead for an allochthonous origin, the fossil plant remains being probably transported from long distances (several kilometers?) into the basin (delta?) during the autumn floods. The presence of foliar impressions of coriacee and subcoriacee (Fagus, Quercus, Liquidambar etc.) leaves is another argument for an allochthonous origin.

The subordinate representation of remains belonging to plants with presentday correspondents in marshes (Taxodium, Glyptostrobus, Alnus, Byttneriophyllum etc.) indicates that such assemblages were developed in lakes along fluviatile flooding plains separated by the main course of the river by fluvial bars, i.e. a hypautochthonous origin cannot be omitted.

At certain levels, it worth also to be mentioned the presence of large carbonate concretions resulted by $\mathrm{CaCO}_{3}$ cementation of clayey silts. They posses an increased hardness and can be exfoliated along planes which often contain very well preserved plant impressions.

\section{MICROFLORAL CONTENT}

The palinological study of Petrescu et al. (2002) evidenced more than 125 different sporo-pollinic forms in the very rich microflora from Batoți. Among them, the taxa that are very frequent (21-30 grains) or frequent (10-20 grains) are as follows: Dinophyta div.sp., Botryococcus braunii Krutzsch, Laevigatosporites haardti (Potonie.et Ven) Th.et Pf., Leiotrilites asp. microsinusoides W.Krutzsch, L. wolffi wolffi W. Krutzsch, L. wolffi brevis W. Krutzsch., Stereisporites div.,sp., Cedripites crassiundulicristatus (Stelmak) W. Krutzsch., Abiespollenites sibiriciformis (Zaklinskaya) W.Kr., Pinus sg. haploxylon, Pinus sg. diploxylon, Piceapollis planoides W.Kr, Zonalapollenites maximus (Raatz) W. Krutzsch, Zonalapollenites gracilis W.Krutzsch., Momipites punctatus (Potonie) Nagy, Caryapollenites simplex (Potonie) W.Krutzsch, Ulmipollenites undulosus Wolff, Trivestibulopollenites betuloides Pflug, Alnipollenites verus (Potonie) Potonie, Persicariapollenites franconius W.Krutzsch, Cichoreacidites gracilis (Nagy) Nagy, Quercopollenites petrea Nagy, Q. robur Nagy, Faguspollenites verus Raatz. 
The microfloral results confirmed the existence of several species of Fagus and Quercus, established by the study of macroflora.

The authors realized a comparative study of Pontian microflora from Romania and Central Parathetys (Slovakia, Jugoslavia and Hungary). As a conclusion, it was considered that the temperature declined during the Early Pontian, and the climate changed from warm-temperate to temperate one. An evident fall of thermal average took place. This situation changed during the second part of Pontian, as proved by the withdrawal of arcrotertiary forms (Petrescu et al., 2001).

\section{MACROFLORAL CONTENT}

Based on the studies of Petrescu et al. (2002), Ticleanu et al. (2002), and Diaconu (in press), it can be summarized that the Pontian flora from Batoți consists of the following 24 taxa: ?Sequoia gigantea Linee., Taxodium dubium (Sternberg) Heer, Glyptostrobus europaeus (Brogniart) Unger, Platanus platanifolia (Ettingshausen) Knobloch, Liquidambar eropaea Al. Braun Alnus ducalis (Gaudin) Knobloch, A. cecropiaefolia (Ettingshausen) Berger, A. kefersteini, Betula insignis Gaudin, Fagus silesiaca Wallther et Zastannyak, Fagus pliocaenica Saporta, Castanea cf. crenata Siebold et Zuccer, Quercus kovatsi Kovacs, Q. pontica Koch miocaenica Kubat, Quercus cf. macrantheroides Andreanszki, Ulmus pyramidalis Goeppert, Carya serraefolia (Goeppert) Krausel, Pterocarya paradisiaca (Unger) Iljinskaya, Populus populina (Brognt.) Knobloch,. Cornus sp., Acer integerrimum (Viv.) Massal, Vitis teutonica Al. Braun şi Bytneriophyllum tiliaefolium (Al.Braun) Knobloch et Kvacek.

\section{ERATIONS \\ PALEO-PHITOGEOGRAPHICAL, -ECOLOGICAL, AND CLIMATE CONSID-}

The phytogeographical analysis of the present-day corresponding forms leads to the conclusion that the Pontian flora from Batoti consists of the following phytogeographical spectrum of elements: 9 - North American - Atlantic, 3 -East Asian, 3 - Caucasian, 2 - Central European, 1 - North American - Pacific, 1 - Asia Minor, 1 - South-East Asia, 1 - cosmopolite; for other 3 elements, no present-day correspondent were identified.

The dominance of North-American elements, followed by East Asian ones is characteristic for the Upper Miocene flora in Romania. Thus, even if currently the flora from Batoti consists of only $12 \%$ of the total number of species identified in Upper Pontian deposits from Chiuzbaia (Givulescu, 1990), the above mentioned features are similar in both cases.

Another similarity is indicated by the presence of 18 common taxa in the two floral associations. More than that, the dominant elements in the Chiuzbaia assemblages, i.e. Fagus silesiaca and various species of Quercus with lobate leaves are also prevailing in the flora from Batoți, thus providing a very interesting comparative study.

Other comparative elements are provided by the study of Mihajlovič and Lazarevič (1999) on Upper Pontian floral associations from Serbia. 11 taxa, especially Fagus leaves are common in the associations from Batoti and that from Creveni Breg, while three species, among which $G$. europaeus and B. tiliaefolium - which are 
the most frequent coal-generating forms in Pontian, according to Givulescu (1992), are common with the coal-associated flora from Kolubara. The association is fully overlapping that from Cirikova, where A. cecropiaefolia can be added. Mihajlovič and Lazarevič (1999) defined the latter two fauna associations as "lignite facies".

The paleoecological study of the flora from Batoți indicated the presence of two distinctive paleobiotopes: a mesophytic biotope characterized by the presence of an allochthonous flora dominated by Fagus, Quercus, Castanea, Carya and Pterocarya etc. and a marsh-type, coal-generating one with G. europaeus, B. tiliaefolium and A. cecropiaefolium. The latter may include forms that are typical for the seasonally flooded areas (A. cecropiaefolia and B. tiliaefolium), or for areas almost permanently flooded, where Taxodium dubium şi G. europaeus were dominant. Besides, the development of a high-hills, possibly mountain-type paleobiotope with Sequoia gigantea cannot be excluded.

Concerning climate parameters, the study of Petrescu et al. (2002) estimated an annual average temperature between $14-15^{\circ} \mathrm{C}$, and precipitations of more than $1200 \mathrm{~mm} /$ year.

The vegetal floor seems to have consisted of an azonal vegetation with wood marshes with $B$. tiliaefolium and $A$. cecropiaefolia şi $L$. europaea, as well as wood marshes with $G$. europaeus and $T$. dubium. Another azonal element of the vegetation the river meadows, have probably included Platanus platanifolia, Salix varians, Populus populina etc. The zonal vegetation consisted of at least two vegetation stages: a field, eventually hill-type one with Fagus woods associated with various species of Quercus, Castanea, Pterocarya, and a second one of coniferous woods in relatively higher areas (high hills), dominated by Sequoia gigantea.

In conclusion, the flora from Batoți represents the only Lower Pontian assemblage described until now from Romania. The 24 identified taxa, that will be followed by other 15 ones under study, and probably many others still left to be discovered in the deposits during further research build-up a paleofloral association of a very special scientific importance. In addition, it can be said that no other similar microflora - as far as its richness and diversity are concerned - is known from Romania and its neighboring areas (Petrescu et al., 2002). All these arguments plead for including the Lower Pontian deposits rich in fossil plants from Batoți among the protected geological, paleontological sites.

\section{REFERENCES}

Brockman, C.F., 1968, Trees of North America. Western Publ.Co., Golden Press, New York

Ghenea, C., Chenea, A. 1962, Câteva observațiuni geologice asupra PREZENȚEI Ponțianului dintre Tr. Severin şi Batoți. D.S. Inst. Geol. XLVI, p.199-205, Bucureşti

Givulescu R., 1979, Palaobotanische Untersuchungen im Pflanzenfundort Chiuzbaia (Maramureş). Inst.geol.Geofiz., Memorii 28, p.1-81, Bucureşti

Givulescu R., 1990, Flora fosilă a Miocenului superior de la Chiuzbaia. Edit. Acad. Rom., 235 p., Bucureşti 
Givulescu R., 1992, Les forets marecageuses du Miocene superieur de Romanie: une palaeobiotop d'exception et sa vegetation dans le Miocene superieur de l'ouest de la Romanie. In: Kovar-Eder J. (ed.) Paleaovegetational developement in Europe and regions relevant to its palaeofloristic evolution, p.147-151, Wien

Maxim, I.Al., Petrescu, I.1968, Plante din Pliocenul de la Derna. Studia Univ. Babeş-Bolyai, s. Geol.-Geogr.,1, p.7-15, Cluj Napoca

Mihajlovic D, Lazarevic Z., 1999, Three Late pontian leaf-floras from Northern Serbia reflecting different environments. Acta Paleobot.Suppl. 2:341-347, Proceedings $5^{\text {th }}$ EPPC. Krakow

Petrescu I., Mălan, L. (1991) Contribuții la cunoaşterea microflorei din Neogenul superior de la est de Turnu Severin. Contribuții botanice, p.135-143, Cluj-Napoca

Petrescu, I., Bican-Brişan, N., Meilescu, C., Pătruțiu, I 2001, Palynological researches concerning the Ponțian on the Vişenilor Valley and Boereasca Valley - NE of Drobeta Turnu Severin (SW - rn Romania). Studia Univ. Babeş-Bolyai, s.Geol.-Geogr., Cluj-Napoca

Petrescu I., Bican-Brişan, N., Meilescu C., Pătruțoiu I. (2002) The palynology oh the Ponțian from Batoți-Mehedinți (South-Western Romania). Acta palaeontologica, 3, Cluj Napoca

Popescu S.-M.(2001) Vegetation, climat et cyclostratigraphie en Paratethys centrale au Miocene superieur et au Pliocene inferieur d'apres palynologie. These de doctorat, Univ.Claude Bernard, Lyon 1

Țicleanu N. (1992) studiul genetic al principalelor zăcăminte de cărbuni neogeni pe baza paleofitocenozelor caracteristice, cu privire la cărbunii plioceni din Oltenia. Teză de doctorat, Univ.Bucureşti

Țicleanu N., Radu A. \& Drăgănescu A. (1975) Contribuții la cunoaterea florei Ponțianului de la Visag (Jud.Timiş).D.S.Inst.Geol. Geof, LXI, Bucureşti

Țicleanu, N., Petrescu I., Diaconu, F., Meilescu C., Pătruțoiu I., 2002, Fossil plants from Pontian deposits at Batoți - Mehedinți. Studia Univ. Babeş-Bolyai, Geol. spec. issue, 1, p.351-364

Zastawniak E. (1972) Pliocene leaf flora from Domanski Wiewrek near Czarny Dunajek (Western Carpathians, Poland). Acta paleo-botanica, XIII, 1, Krakow. 